\title{
A SUPERAÇÃO DA TENSÃO EXISTENTE ENTRE AS AGÊNCIAS REGULADORAS BRASILEIRAS E O REGIME DEMOCRÁTICO
}

\author{
Kate de Oliveira Moura ${ }^{358}$ \\ Otacílio dos Santos Silveira Neto ${ }^{359}$
}

Recebido em:30/11/2017

Aprovado em: 13/05/2017

\begin{abstract}
RESUMO
O presente trabalho tem por escopo estudar as agências reguladoras brasileiras sob a perspectiva do suposto déficit democrático atribuído a essas autarquias de regime especial. Inicialmente, serão destacadas as premissas no que tange a relação existente entre democracia e agências reguladoras no contexto do neoliberalismo. Em seguida, será feito uma análise a respeito da tensão existente entre as agências reguladoras brasileiras e o regime democrático. Assim, serão tecidos comentários a respeito da aferição de democracia dentro do modelo regulatório. $\mathrm{O}$ objetivo é demonstrar as diversas vias de legitimidade democrática observadas pela doutrina, quais sejam: i) a legitimidade democrática pelo título, isto é, com o sufrágio universal e; ii) a legitimidade pelo exercício do poder, pelo qual a atuação das agências se legitima pela perseguição incessante do interesse público. Na sequência, será vista a questão da participação popular no processo decisório das agências reguladoras como pressuposto indispensável para o alcance de uma regulação setorial democrática associado ao cumprimento das finalidades públicas destinadas a tais entes.
\end{abstract}

Palavras-Chaves: Agências Reguladoras Brasileiras. Suposto Déficit Democrático. Legitimidade pelo exercício do poder.

\section{INTRODUÇÃO}

\footnotetext{
${ }^{358}$ Mestranda em Direito Constitucional pela Universidade Federal do Rio Grande do Norte - UFRN. Advogada. 359 Doutor em Direito Público pela Universidade de Zaragoza, Espanha. Mestre em Ciências Jurídicas pela Universidade Federal da Paraíba (UFPB). Professor Adjunto do Departamento de Direito Público da Universidade Federal do Rio Grande do Norte. Na condição de professor permanente, integra o Programa de Pós-Graduação em Direito da UFRN e na de colaborador o Programa de Pós-Graduação em Direito Mestrado na UFRN e em Mestrado/Doutorado na UFPB.
} 
As agências reguladoras brasileiras, adotadas na década de 1990, foram inspiradas principalmente no modelo regulatório norte-americano, e, portanto, consideradas figuras recentes no cenário socioeconômico brasileiro. Tais institutos são destinados à regulação estatal sobre o domínio econômico em setores específicos e estratégicos.

As referidas agências são fruto de um processo de reaparelhamento estatal caracterizado pela transição de um Estado Intervencionista para um Estado Regulador. Tendo por intuito atuar sobre a economia de forma politicamente independente, essas agências são dotadas de autonomia financeira e administrativa, ponderando e harmonizando os diversos interesses contrapostos envolvidos entre os seus regulados: o Estado (interesse político), os agentes econômicos (interesse econômico) e os cidadãos (interesses coletivos).

Para a consecução das atribuições a elas destinadas, com medidas muitas vezes impopulares, era, portanto, primacial que lhes fossem asseguradas o distanciamento de pressões político-partidárias, garantindo sua tecnicidade-científica.

Nesse ínterim, com o intuito de promover uma regulação técnica, imparcial e eficiente, as agências reguladoras foram dotadas de uma autonomia qualificada, que se subdivide em autonomia política, autonomia orgânica, autonomia normativa, independência técnica decisional e, por fim, em independência gerencial, financeira e orçamentária.

No entanto, essa autonomia reforçada frente ao Poder Constituído deu ensejo a uma série de contundentes críticas por parte dos estudiosos. A preocupação era que essas agências representassem a constituição de um poder paralelo, que abrange funções executivas, legislativas e judiciárias, e que estaria pouco sujeita aos mecanismos clássicos de controle político e social.

Dentre os inúmeros desafios enfrentados pelas agências, ressalta-se a crise de legalidade, a crise com o sistema de freios e contrapesos e a crise de legitimidade.

Todavia, o debate atual no que tange aos entes regulatórios concentra-se em sua suposta deficiência democrática, especialmente quando se percebe a importância dos instrumentos regulatórios enquanto ferramentas aptas à promoção de valores e direitos fundamentais, bem como ao atendimento das finalidades públicas para a consagração de uma regulação verdadeiramente democrática, o que será objeto de estudo no trabalho a seguir.

\section{O MODELO REGULATÓRIO BRASILEIRO NO CONTEXTO NEOLIBERAL}


Para alguns estudiosos do Direito, a exemplo de Eros Grau ${ }^{360}$, existe uma contradição entre o neoliberalismo, de ideologia excludente e de marginalização, com a democracia, que pressupõe um número cada vez maior de cidadãos tendo acessos a bens sociais e direitos. Teoricamente, são conceitos considerados ontologicamente contrapostos, o que faz do Estado Democrático de Direito o principal inimigo do neoliberalismo ${ }^{361}$.

Nada obstante, desde a Segunda Guerra Mundial o processo de consolidação e evolução regulatória vem se desenvolvendo nos Estados visivelmente democráticos ${ }^{362}$.

Malgrado as diversas críticas que rodeiam o Capitalismo, esquece-se os intelectuais qual seria a sua principal virtude: a sua capacidade de transformação, de modo a assegurar a reprodução de suas relações capitalistas, mesmo envolta a movimentos de ampliação e concretização de direitos e garantias ${ }^{363}$.

Ato contínuo, um dos efeitos perceptíveis do pós-Segunda Guerra Mundial foi o surgimento de uma nova forma de administrar a coisa pública, notadamente com o fortalecimento do Executivo. É nesse contexto que se prolifera a ideia de um modelo regulatório, com o surgimento das agências reguladoras, adaptando-se a Administração Pública aos novos anseios do Estado Constitucional e Democrático de Direito.

Imperativo rememorar a importância do princípio da legalidade com o advento do Estado Moderno, na perspectiva de proteger os indivíduos contra os possíveis abusos e arbitrariedades do Poder Público. Isso porque todo dever de ação ou de inação do Estado deveria estar amparado em uma lei estrita, de sorte que o ente público só pode restringir ou limitar

\footnotetext{
${ }^{360}$ GRAU, Eros Roberto. A Ordem Econômica na Constituição de 1988. 5 ed. São Paulo: Malheiros Editores, 2000, p. 133.

${ }^{361}$ Salutar apresentar o contraponto a respeito do termo "neoliberalismo". Nessa esteira, defende Thiago Gomes: "Neoliberalismo sempre foi um conceito confuso. Em quase todas as situações é citado de forma negativa: tratase de um mau sistema. Isso ocorre porque o neoliberalismo é visto como representação ideológica máxima do capitalismo. E o sistema capitalista é dividido em duas classes: capitalistas e explorados. Os primeiros exploram os segundos através da mais-valia. Essa linha de pensamento é tipicamente marxista. O neoliberalismo, então, seria sinônimo de livre mercado: desmantelamento do Estado de Bem-Estar Social, desregulamentação de mercados, proteção da propriedade capitalista, entre outras ações. E o governo cuidando das pessoas é uma forma de amenizar o mal que o sistema capitalista causa nas pessoas. Se aceitarmos tais termos, estamos caindo num debate claramente marxista. E aceitar o marxismo é cair numa discussão apenas ideológica. [...]. Quando se associa o liberalismo de alguma forma às propostas do $\mathrm{CW}$ ou do livre mercado, está se cometendo uma falácia, pois de nenhuma forma as ditas propostas (no conjunto, como vimos) neoliberais representam propostas de uma economia de mercado. Então, a questão é mais profunda do que a pura linguística. É questão de não cometer erros conceituais na investigação sobre o grau de intervenção e liberdade na economia. Neoliberalismo não existe. O Consenso de Washington possui propostas neo-intervencionistas. Os países que reformaram sua política econômica nos anos 1990 buscaram o neo-intervencionismo. O período pelo qual passamos na década passada e continuamos até hoje pode se chamar a Era do Novo Intervencionismo" (GOMES, Thiago Beserra. O conceito de neoliberalismo. Instituto Ludwing von Mises Brasil. 2010).

362 MARTINS, Fernando Barbalho. A legitimidade democrática das agências reguladoras. Revista de Direito Processual Geral. n. 58, Rio de Janeiro, 2004, p. 74.

363 GRAU, Eros Roberto. A Ordem Econômica na Constituição de 1988. 2000, p. 58-59.
} 
direitos, liberdades e garantias se autorizado por ele, e seguindo estritamente os parâmetros legais. Ou seja, toda a atuação da Administração Pública tem como cerne o princípio da legalidade, fundamentando e legitimando sua atuação.

Em contraposição, vivencia-se, nos dias atuais, um Poder Legislativo atônito às mudanças socioeconômicas, seja: i) pela estrutura colegiada e deliberativa que torna naturalmente a sua função morosa; ii) pela má vontade dos parlamentares de se insurgir contra o eleitorado com a aprovação de medidas impopulares; iii) pela sua insuficiência técnica para compreender e enfrentar os problemas advindos do pós-modernismo; iv) por não dispor de instrumentos legiferantes céleres no intuito de responder a tempo, e de forma eficiente, as constantes transformações socioeconômicas decorrentes de um mundo extremamente competitivo. Desse modo, percebemos ausência de instrumentos legais adequados para as novas circunstâncias fáticas e sociais que vão se firmando no mundo contemporâneo.

O fato é que se começou a se difundir a ideia de instrumentalizar e fortalecer os órgãos do Executivo para enfrentar as mudanças rápidas de uma sociedade informacional, sendo as Agências Reguladoras, o mecanismo pelo qual se poderia promover a regulação do Estado sobre o domínio econômico de modo adequado e eficiente, nos termos do art. 174 da Constituição Federal.

Ao se instrumentalizar o Executivo, na pessoa das Agências Reguladoras, por exemplo, seria possível regular e se antecipar às inovações e, consequentemente, novas relações que estavam sendo formadas, haja vista tais órgão já estarem inseridos em um novo modelo de gestão que primava pela tecnicidade, eficiência e imparcialidade.

Nesse espeque, o legalismo formal e dogmático, cuja edição de leis era de competência exclusiva do Poder Legislativo, perdeu forças em face do fortalecimento e hipertrofia do Poder Executivo. Cuida-se do fenômeno da fragmentação normativa ${ }^{364}$, em que é delegado a um conjunto de entes e órgãos da Administração o poder de normatizar.

Assim, a lei formal foi suplantada pelo regulamento executivo a fim de regulamentar o planejamento econômico e as finanças públicas. Nas palavras de Carlos Castro ${ }^{365}$, "era, enfim, o Direito Regulamentar Econômico, vencendo as barreiras do exclusivismo parlamentar no campo da criação normativa e ultrapassando o processo legislativo ordinário".

\footnotetext{
364 CASTRO, Carlos Roberto Siqueira. Função Normativa Regulatória e o Novo Princípio da Legalidade. In: ARAGÃO, Alexandre Santos. (Org.). O Poder Normativo das Agências Reguladoras. 2 ed. Rio de Janeiro: Editora Forense, 2005, p. 29.

365 Ibidem, p. 42.
} 
Não se está dizendo que o princípio da legalidade foi deixado de lado. O que ocorreu foi que a lei formal, cujo conteúdo é geral e abstrato, cedeu espaço para a surgimento de outros atos administrativos (portarias e resoluções, por exemplo) na tentativa de juridicizar toda o plexo de relações existentes entre o Estado e os seus administrados - princípio da juridicidade - eliminando lacunas e incertezas jurídicas, ao mesmo tempo em que almeja a eficiência e celeridade na atuação administrativa.

Nessa linha, esses atos normativos não seguem o rito formal e naturalmente moroso de edição das leis com o intermédio da participação popular, representada pelas Casas Legislativas. Ao contrário, são dotadas de aptidão para regulamentar setores, em geral, não disciplinados pela lei em sentido formal, mas com fundamento na Lei Maior, fenômeno chamado de deslegalização $o^{366}$ ou degradação de grau hierárquico ${ }^{367}$.

Por esse viés que se questiona hodiernamente a legitimidade democrática de tais atos normativos, haja vista que são editados por autarquias de regime especial, cujos dirigentes não são eleitos pelo povo, mas sim indicados pelo Chefe do Poder Executivo e sabatinados pelo Casa Legislativa.

A situação se agrava especialmente frente a cultura brasileira de excessiva normatização. Ou seja, tende-se a normatizar tudo, editando, a todo momento, uma gama de atos normativos, o que desencadeia um grave problema, a saber, o próprio descrédito social com relação aos textos normativos.

Interessante notar, contudo, que as novas ferramentas de regulação setorial coexistem com os instrumentos regulatórios próprios da tradição liberal-burguesa. Até porque, muitas das

\footnotetext{
${ }^{366}$ Com propriedade, Patrícia Batista observa: "Tradicionalmente, nos países que se inspiraram no modelo francês, o conteúdo deste princípio (o da legalidade) foi associado à ideia de vinculação positiva à lei: à Administração somente é lícito fazer aquilo que a lei expressamente autoriza. Entretanto, com a superação do Estado liberal, e a crise da lei formal, desapareceram as condições que justificavam a tese da vinculação positiva à lei. A deslegalização, por meio da qual, se abre ao poder regulamentar o trato de matérias antes atribuídas ao poder legislativo, é uma das provas da insuficiência daquela tese para a realidade contemporânea. Desenvolveu-se, assim, a teoria da vinculação da Administração ao Direito, especialmente aos princípios e regras do ordenamento constitucional. Subsiste, de qualquer forma, a regra da vinculação positiva à lei para aquelas matérias submetidas, pelo constituinte, à reserva de lei e para as atividades de natureza gravosa, passíveis de limitar ou extinguir direitos subjetivos dos administrados”. (BATISTA, Patrícia Ferreira apud BARROSO, Luís Roberto. Constituição, Ordem Econômica e Agências Reguladoras. Revista Eletrônica de Direito Administrativo Econômico. Instituto de Direito Público da Bahia, Salvador, fev/abr, 2005, p. 29).

${ }^{367}$ Com relação ao fenômeno intitulado como a degradação de grau hierárquico, Leonardo Figueiredo explica: "Neste caso, uma lei, sem entrar na regulação da matéria, rebaixa formalmente o seu grau normativo, permitindo que essa matéria possa vir a ser modificada por regulamento". (FIGUEIREDO, Leonardo Vizeu. Lições de Direito Econômico. 2 ed. Rio de Janeiro: Forense. 2009, p 168).
} 
novas e atuais características das agências de regime especial nada mais são do que um aperfeiçoamento e uma evolução das antigas formas regulatórias ${ }^{368}$.

Ao se analisar de forma mais aprofundada o contexto firmado no Brasil, nota-se que vários são os desafios enfrentados atualmente pelas agências reguladoras, sobretudo ao se considerar a importação de um modelo estadunidense pré-concebido, sem que fossem feitas as devidas adequações no que tange as especificidades da realidade política, econômica e social brasileira.

Percebendo essa realidade, Alexandre dos Santos Aragão ${ }^{369}$ enumera dez características principais das agências reguladoras brasileiras no cenário atual, os quais, de forma resumida, elenca-se abaixo:

i) a abrangência setorial: as agências devem atuar em muitas áreas, de forma especializada, por meio de fragmentação das normas jurídicas tendo por escopo evitar atividades de cunho nefastas, ao mesmo tempo em que promove a busca das finalidades públicas;

ii) a subdeterminação: correspondente ao estabelecimento de normas gerais e flexíveis para que o agente regulador, com sua "discricionariedade técnica" promova o grau de tecnicidade e especialização que a norma precisa para atingir a sua finalidade, adaptando-se as constantes e, muitas vezes, inesperadas mudanças da economia;

iii) a autonomia institucional: em face da autonomia ${ }^{370}$ de que gozam frente ao Poder Executivo Central, tais entes afastam-se de decisões eminentemente políticopartidárias que possam pôr em xeque a tecnicidade e autonomia que lhes é característica;

iv) a instrumentalidade e a flexibilidade: consiste na tecnicidade típica da regulação, de modo que seus atos normativos constituem verdadeiros "instrumentos de políticas finalísticas";

${ }^{368}$ ARAGÃO, Alexandre dos Santos. O Atual Estágio de Regulação Estatal. In: ARAGÃO, Alexandre dos Santos. Agências Reguladoras e a Evolução do Direito Administrativo Econômico. 2 ed. Rio de Janeiro: Forense, 2005 , p. 83.

369 Ibidem, p. 84-114.

${ }^{370} \mathrm{O}$ termo mais apropriado com relação à autonomia reforçada das agências reguladoras é que elas gozam de uma autonomia frente ao Governo Central, mas isso não quer dizer que são independentes. Apesar de parecer similares, as nomenclaturas 'autonomia' e 'independência' são ontologicamente distintas. A independência consiste em uma ampla liberdade na sua função regulatória sobre economia, configurando um órgão totalmente independente para a escolha de metas e meios utilizados para se alcançar as suas finalidades, funcionando praticamente como um quarto poder. A autonomia, por sua vez, corresponde a uma atuação regrada dentro de parâmetros legais prédefinidos. Sobre a temática: "É importante chamar a atenção para o fato de que a agência reguladora não é um quarto poder, mas sim um ente integrante da própria Administração Pública indireta e, portanto, submetida aos comandos do administrador, com a vantagem de estar protegida contra as interferências de ordem política sobre a sua atuação, que deve ser técnica" (SILVA, Eduardo Marques da. A independência das Agências Reguladoras no Brasil e o Projeto de Lei no 3.337/2004. Rio de Janeiro. Prêmio SEAE, 2006, p. 53). 
v) a permeabilidade: atributo que conecta o Direito às demais áreas do conhecimento a fim de propiciar uma regulação eficiente e com maior efetividade;

vi) a administrativização: fenômeno da desconcentração do Poder, em que a Administração outorga poderes normativos à vários entes e órgãos buscando melhor atender o interesse público com o maior grau de eficiência;

vii) os novos mecanismos de legitimação: consistente na busca por ferramentas que possam suprir o suposto déficit democrático das agências reguladoras, com a consecução das finalidades públicas atribuídas às agências pelo marco regulatório (legitimação pelo exercício do poder), bem como pela criação de espaços públicos de discussão no seio do processo decisório desses entes administrativos;

viii) a setorização: necessidade de coordenação ante a multiplicação e setorização dos diversos agentes regulatórios existentes, com a criação de mecanismos que propiciem a solução harmoniosa de possíveis conflitos entre as agências reguladoras no que tange à atividade regulatória;

ix) a individualização e a concretude: diante da complexidade e pluralismo que permeia a sociedade brasileira, faz-se necessário a multiplicação do número de medidas que podem ser tomadas pelas agências de regime especial ante o caso concreto, visando a concretização dos objetivos por elas colimados e;

x) a consensualidade: habilidade que as agências reguladoras possuem de buscar a consecução dos seus objetivos da forma mais consensual possível e menos autoritária.

Diante do grande grau de intervenção das agências reguladoras nas atividades privadas, somadas a sua questionável eficiência no que tange a regulação econômicas de setores econômicos importantes, bem como a sua não sujeição aos controles políticos e sociais tradicionais deflagraram uma série de intensas e contundentes críticas a seu respeito ${ }^{371}$.

\section{A TENSÃO DEMOCRÁTICA ENTRE OS AGENTES REGULADORES BRASILEIROS E O REGIME DEMOCRÁTICO}

\footnotetext{
${ }^{371}$ Corroborando esse posicionamento, interessante trazer à baila da análise a reflexão crítica tecidas por Joaquim Barbosa, in verbis: “(...) sobre elas têm sido suscitadas questionamentos jurídicos-constitucionais dos mais variados matizes, envolvendo desde a falta de legitimidade democrática e de compromisso para com o princípio de separação dos poderes, que lhes seria inerente, passando pela crítica ao seu modo de atuação e ao suposto 'despotismo' que elas encarnariam, na medida em que, comandadas por técnicos e experts supostamente apolíticos e equidistantes das lutas pelo poder que se travam entre as diversas facções em que se divide o corpo social, essas entidades em realidade estariam se subtraindo ao procedimento democrático de controle instrumentalizado através do processo político ('political accountability')". (BARBOSA GOMES, Joaquim Benedito apud MARTINS, Fernando Barbalho. A legitimidade democrática das agências reguladoras. Revista de Direito processual Geral. n. 58, Rio de Janeiro, 2004, p. 74-75).
} 
Debruçando-se sobre o tema em apreço, Gustavo Binenbojm ${ }^{372}$ elenca três problemas centrais neste atual momento histórico no que concerne às agências reguladoras, quais sejam, a) a tensão com o princípio da legalidade; b) a tensão com o sistema da separação de poderes e de freios e contrapesos; e c) a tensão com o regime democrático.

Entretanto, convém destacar que o objeto de estudo do presente trabalho irá se debruçar estritamente ao terceiro problema apontado, e, especificamente a uma das facetas da possível ausência de legitimidade ${ }^{373}$ das agências reguladoras e suas implicações para uma regulação setorial legitimamente democrática e eficiente, conforme se verá adiante.

De fato, em que pese os outros problemas elencados, a grande discussão sobre as agências reguladoras há muito tempo deixou de ser em razão de sua autonomia qualificada para ser em relação ao seu controle social e político, sua responsividade social e sua legitimidade democrática ${ }^{374}$.

Ante as considerações iniciais no que tange à incorporação das agências reguladoras no cenário brasileiro aliado ao contemporâneo estágio em que se encontra a regulação pátria, resta imperioso uma análise perscrutas a respeito compatibilidade entre esse sistema regulatório com o princípio democrático ${ }^{375}$, tendo como fundamento o artigo $1^{\circ}$ da Constituição Federal.

372 BINENBOJM, Gustavo. Agências reguladoras, legalidade e direitos fundamentais - limites aos poderes normativo e sancionatório da ANVISA na regulação de produtos fumígenos. Revista de Direito Público da Economia, Belo Horizonte, v. 3, n. 10, abr. 2005, p. 486.

${ }^{373}$ Em uma abordagem mais crítica, preleciona Gustavo Binenbojm: "Historicamente, o problema da legitimidade da Administração Pública sempre foi reconduzido aos mecanismos de legitimação dos Poderes Legislativos e Executivo. Em relação ao Legislativo, invocava-se a lei (produto da vontade geral, ou ao menos da vontade dos agentes eleitos) como fonte da autoridade da Administração. Em relação ao Executivo, remetia-se a condução dos negócios administrativos diretamente ao Presidente ou Primeiro-Ministro, escolhidos, de forma imediata ou não, pelo voto popular. É fácil entender por que ambos os argumentos são insatisfatórios. De um lado, a lei é, em geral, um quadro ou uma simples moldura da atuação administrativa. Somente por ignorância ou cinismo alguém poderá negar o (maior ou menor) conteúdo volitivo das decisões administrativas ainda que tomadas dentro dos limites legais. De outra parte, não há como considerar toda a atividade administrativa um produto da vontade do Chefe do Executivo. O cotidiano da Administração demonstra que é enorme o grau de pulverização das decisões, sendo a maioria delas tomadas por burocratas profissionais. Tal situação - de déficit de legitimidade - se agrava agudamente quando considerada a proliferação de autoridades administrativas independentes. É que os fundamentos de sua atividade costumam ser leis dotadas de elevado grau de vagueza, generalidade e abstração, que transferem aos administradores inúmeras decisões de cunho político. Ademais, a não inclusão das agências na linha hierárquica direta do Chefe do Poder Executivo esvazia por completo o segundo argumento, já que a legitimidade decorrente da investidura popular deste não se transfere a reguladores autônomos" (BINENBOJM, Gustavo. Uma Teoria do Direito Administrativo: Direitos Fundamentais, Democracia e Constitucionalização. Rio de Janeiro: Renovar, 2006, p. 289).

374 BINENBOJM, Gustavo. Agências reguladoras, legalidade e direitos fundamentais: limites aos poderes normativo e sancionatório da ANVISA na regulação de produtos fumígenos. Revista de Direito Público da Economia, Belo Horizonte, v. 3, n. 10, abr. 2005, p. 485.

${ }^{375} \mathrm{O}$ artigo $1^{\circ}$ da Constituição Federal de 1988 assim estabelece: “A república federativa do Brasil, formado pela união indissolúvel dos Estados e Municípios e do Distrito Federal, constitui-se em Estado Democrático de Direito e tem como fundamentos [...]". Não obstante, tal previsão, conforme adverte Fernando Barbalho, também se 


\subsection{A Aferição da Democracia no Contexto Regulatório}

Neste ínterim, salutar a compreensão do que seria democracia, trazendo à baila da discussão a sua relação com as agências reguladoras no intuito de se diagnosticar o suposto déficit democrático atribuído a tais entes administrativos.

Cumpre ressaltar que a despeito da impossibilidade de se determinar um conceito hermético e universal de democracia capaz de contemplar toda a sorte de experiência democrática concreta, faz-se necessário uma breve noção conceitual que trate do núcleo deste instituto. A despeito da nomenclatura "democracia" ser um conceito que apresenta múltiplas facetas, ela não pode significar "qualquer coisa".

Segundo parte da doutrina ${ }^{376}$, há três grandes teorias da democracia. A primeira, a teoria clássica, conhecida como aristotélica, vê a democracia como o governo do povo. A segunda, a teoria medieval, vê a democracia sob duas perspectivas, ou deriva do povo e se torna uma democracia representativa, ou deriva do príncipe, e se transmite de forma hereditária. A terceira, a teoria moderna, vê a democracia como uma forma de república.

Visando conceituar democracia, Bobbio, Mateucci e Pasquino ${ }^{377}$ afirmam tratar-se de "um método, ou um conjunto de regras de procedimento para a constituição do Governo e para a formação das decisões políticas (ou seja, das decisões que abrangem toda a comunidade) mais do que determinada ideologia". A partir de tal definição, nota-se que os mencionados professores, ao enunciarem que democracia se trata de um "conjunto de regras", trazem à tona a ideia de democracia procedimental, bem como que a conteúdo da decisão é fruto da regra da maioria.

Ocorre que esta compreensão se revela insuficiente, pois difunde a ideia equivocada de que a democracia se constrói basicamente pela formação da vontade da maioria.

Ora, não se pode construir uma democracia efetiva quando se está diante de uma preponderância absoluta e ilimitada da vontade da maioria, colocando em risco os direitos da

encontra prevista no corpo do preâmbulo, assim dispondo: "Nós, representantes do povo brasileiro, reunidos em Assembleia Nacional Constituinte para instituir um Estado Democrático [...]”. (MARTINS, Fernando Barbalho. A legitimidade democrática das agências reguladoras. Revista de Direito processual Geral, Rio de Janeiro, n. 58, 2004, p. 37).

376 TABORDA, Marem Guimarães. O princípio da publicidade e a participação na Administração Pública. 2006. 215 f. Tese (Doutorado) - Curso de Direito, Universidade Federal do Rio Grande do Sul, Porto Alegre, 2006, p. 30 .

377 BOBBIO, Norberto; MATTEUCCI, Nicola; PASQUINO, Gianfranco. Dicionário de Política. 5 ed. Brasília: Ed. Universidade de Brasília. 1999, p. 326. 
minoria. Ora, deve haver uma harmonia entre a vontade da maioria com o respeito aos direitos das minorias, dirimindo possíveis abusos de poder perpetrados pela parcela majoritária.

No que concerne a expressão déficit democrático, esta foi utilizada pela primeira vez por David Marquand em $1979^{378}$ e teve como origem a experiência oriunda da Comunidade Europeia, quando os membros do Parlamento Europeu eram indicados diretamente pelos parlamentares de cada nacionalidade. Restringia-se, assim, a questão da ausência de um sistema de eleições diretas, em que a população civil pudesse escolher de forma legítima seus representantes para o bloco europeu.

Mais tarde, o termo ganhou visibilidade, especialmente pela maturidade democrática com que os países estavam vivenciando e tornou-se mais abrangente. Na visão hodierna, o déficit democrático corresponde a ausência de mecanismos de participação direta do cidadão nas decisões que corresponderão a vontade política da nação, bem como na violação a concepção clássica de tripartição de poderes ${ }^{379}$.

Logo, a expressão que nasceu no seio da Comunidade Europeia caiu como luva na discussão sobre a legitimidade democrática das agências reguladoras no Brasil, particularmente em decorrência da inexistência de participação direta do povo nas escolhas dos dirigentes das agências reguladoras, bem como do processo decisório normativo de tais entes $\operatorname{administrativos}^{380}$.

Ora, não se pode negar o status democrático das agências de regime especial tão somente pela inobservância de processo eletivo como forma de ingresso dos seus dirigentes. $\mathrm{O}$ ingresso de dirigentes por meio do direito fundamental ao sufrágio universal não é condição sine qua non para que se configure um déficit na democracia. Nem poderia! A forma eletiva

\footnotetext{
378 MARTINS, Aluisio de Souza. Agências Reguladoras e os Riscos da Captura pelos Entes Regulados: Estudo Comparativo entre o Direito Regulatório Norte-Americano e o Brasileiro, 2010. Dissertação (Mestrado em Direito Internacional Econômico) - Faculdade de Direito, Universidade Católica de Brasília, Brasília, p. 80.

379 JUSTEN FILHO, Marçal. Agências Reguladoras e Democracia: Existe um Déficit Democrático na "Regulação Independente"? In: ARAGÃO, Alexandre Santos. (Org.). O Poder Normativo das Agências Reguladoras. Rio de Janeiro: Forense, 2006, p. 228.

${ }^{380}$ Sob uma análise perscrutas, Maren Taborda expõe: “[...] a democracia brasileira é do tipo 'procedimentaldeliberativa porque o 'processo de tomada de decisões está orientado antecipadamente.' Além disso, há a deliberação pública sobre o que é o bem comum, e essa deliberação, para ser democrática, deve conter a mais ampla participação possível do povo. Todavia, dado que, nas sociedades reais, bastante complexas, o 'sistema administrativo', ao assumir cada vez mais tarefas de regulação, sobrecarrega o modo deliberativo de decisão, de modo que o poder administrativo se torna um poder autônomo, sem relação alguma, mesmo indireta, com a vontade a que ele está sendo submetido através da mediação da representação.” (TABORDA, Marem Guimarães. O princípio da publicidade e a participação na Administração Pública. 2006. 215 f. Tese (Doutorado) - Curso de Direito, Universidade Federal do Rio Grande do Sul, Porto Alegre, 2006, p. 40).
} 
deve andar de braços dados com a consecução de preceitos fundamentais, caso contrário, poderia tornar-se, na realidade, uma ferramenta de exclusão ${ }^{381}$.

É bem verdade que a democracia pressupõe que certos cargos e funções sejam, de fato, ocupados por sujeitos escolhidos pela vontade popular, de sorte que as decisões políticas possam refletir a legítima vontade da nação ${ }^{382}$, mas isso não condiz com a violação dos interesses e direitos das minorias, que devem ser assegurados ainda que contra a vontade da parcela majoritária da população.

Com efeito, a democracia não quer dizer tão somente a participação da população na formação da vontade da nação, mas também que esse processo esteja em compasso com a observação de preceitos e limites constitucionais. Caso contrário, estar-se-ia diante da ditadura da maioria e não de uma democracia.

A um primeiro olhar, pode parecer que a contemporânea forma de regulação brasileira pode ensejar a mitigação do princípio democrático na medida em que os dirigentes das agências não são eleitos democraticamente pelo povo. No entanto, como já advertido nas linhas acima, a simples ausência de processo eletivo não implica necessariamente em uma deficiência democrática de tais entes.

Para os críticos, a exemplo de Paulo Mattos ${ }^{383}$, haveria uma salutar diferença entre a legitimidade do conteúdo decisório oriundo de um órgão colegiado não eleito e independente da Administração Direta e a decisão monocrática de um Ministro de Estado nomeado pelo Presidente da República, legitimamente eleito pelo sufrágio universal ${ }^{384}$.

Entretanto, deve-se ressaltar que a democracia nunca poderá ser reduzirá apenas aos processos eletivos. O que a Constituição Federal impõe é que os representantes de determinados cargos e funções sejam escolhidos por meio de voto, mas não que todo e qualquer provimento

\footnotetext{
381 MOURA, Kate de Oliveira; XAVIER, Maria Augusta Marques de Almeida. A Participação Popular no Processo Decisório das Agências Reguladoras como Pressuposto Indispensável a uma Legítima e Eficiente Regulação Setorial Democrática. Revista Jurídica In Verbis (UFRN), v. 37, jan./jun. 2015, p. 52.

382 JUSTEN FILHO, Marçal. Op. cit., p. 230.

383 MATTOS, Paulo Todescan Lessa. Agências Reguladoras e Democracia: participação pública e desenvolvimento. In: SALOMÃO FILHO, Calixto (Org.). Regulação e Desenvolvimento. São Paulo: Malheiros, 2002, p. 187.

384 Egon Bockman já parte da premissa de que existe um verdadeiro "mal-estar democrático" advindo especificamente do surgimento das agências reguladoras, o que faz com que sejam criados mecanismos aptos a lhe conferir legitimidade (MOREIRA, Egon Bockman. Agências Reguladoras Independentes, Déficit Democrático e a "Elaboração Processual de Normas". Revista de Direito Público da Economia - RDPE. Belo Horizonte, Ano 1, n., jan/mar, 2003, p. 222).
} 
de cargo e função resulte de uma eleição ${ }^{385}$. Além do critério eletivo, há também o critério da meritocracia para o provimento de alguns cargos e funções públicas, como é o caso dos magistrados de Tribunais Superiores.

Desta feita, não há necessariamente insuficiência democrática quando a instituição estatal, malgrado desconstituída de participação popular direta, sujeite-se a realização de valores e princípio constitucionais, bem como atenda às finalidades públicas a ela atribuída ${ }^{386}$. Ainda mais quando se percebe a importância de que determinados entes administrativos autônomos, em certas circunstâncias, venham a se distanciar de decisões eminentemente político-partidárias, tomando decisões mais adequadas e de cunho mais técnico ${ }^{387}$, e que não raras vezes desagradam a eleitorado ${ }^{388}$ - o que não quer dizer que a atividade regulatória não envolva decisões políticas no momento em que para a consecução do interesse público a agência perpassa por um exame de conveniência e oportunidade.

$\mathrm{Na}$ realidade, os entes reguladores podem favorecer uma forma de controle democrático mais eficaz do que a responsabilidade direta perante os eleitores ou os seus representantes ${ }^{389}$. Isto porque os dirigentes das agências reguladores gozam de uma considerável confiança em razão da prevalência do conhecimento técnico e da independência decisória de um expert em comparação a um órgão de responsabilidade política direta ${ }^{390}$.

Todavia, importante ressaltar que o raciocínio de que a legitimação democrática das agências independente não se dá pela via democrática, mas por decisões técnicas que visem a eficiência regulatória pode ensejar uma compreensão equivocada e perniciosa de que

\footnotetext{
385 JUSTEN FILHO, Marçal. Agências Reguladoras e Democracia: Existe um Déficit Democrático na "Regulação Independente"? In: ARAGÃO, Alexandre Santos. (Org.). O Poder Normativo das Agências Reguladoras. Rio de Janeiro: Forense, 2006, p. 232.

${ }^{386}$ MARTINS, Fernando Barbalho. A legitimidade democrática das agências reguladoras. Revista de Direito processual Geral. n. 58, Rio de Janeiro, 2004, p. 83.

387 É o caso, por exemplo, do Banco Central que nas últimas eleições presidenciais de 2014 foi alvo de uma série de críticas quanto a sua autonomia operacional frente ao Poder Executivo, quando alguns candidatos sustentavam a sua total independência.

388 FIDALGO, Carolina Barros. Déficit democrático e legitimação do modelo brasileiro de agências reguladoras independentes através da criação de mecanismos de participação dos administrados. II Prêmio SEAE, Rio de Janeiro, 2007, p. 8-9.

389 Desse modo, oportuno a análise de Alexandre Aragão, ipsi litteris: "Veja-se, por exemplo, as agências reguladoras, cujos dirigentes são nomeados por mandatos certos não coincidentes, propiciando a nomeação deles ao longo dos diversos governos. A medida, longe de se afastar da democracia, com um suposto afastamento destas instâncias das forças políticas majoritárias, assegura o pluralismo no seio do Estado sem retirar totalmente o poder de controle do Chefe do Poder Executivo ou do Poder Legislativo. São, destarte, uma fórmula apta a propiciar a necessária combinação entre o pluralismo e o princípio majoritário. (ARAGÃO, Alexandre dos Santos. A Nova Jurisdição Constitucional Brasileira. Rio de Janeiro: Renovar, 2001, p. 116).

${ }^{390}$ LA SPINTA, Antonio; MAJONE, Giandomenico apud ARAGÃO, Alexandre dos Santos. O Atual Estágio da Regulação Estatal. In: ARAGÃO, Alexandre dos Santos. Agências Reguladoras e a Evolução do Direito Administrativo Econômico. 2 ed. Rio de Janeiro: Forense, 2005, p. 88.
} 
Democracia e Agências Reguladoras Independentes são conceitos autônomos, os quais, no máximo, podem vir a se complementar ${ }^{391}$.

É que a legitimidade democrática e a legitimidade técnica são conceitos que não se equivalem ${ }^{392}$. O primeiro está relacionado ao modo de composição dos órgãos por meio do sufrágio universal; ao passo que o segundo se refere a realização das melhores escolhas tendo baliza no critério técnico-científico.

Ainda que se afirme que os parâmetros norteadores das decisões das agências reguladoras são a racionalidade econômica e a consecução do interesse público e não necessariamente a vontade popular fruto da maioria, esse fato não obsta o reconhecimento da legitimidade democrática às agências independentes.

Neste pórtico, há uma impropriedade lógica na afirmativa de que as agências reguladoras prescindem de legitimidade democrática. Isto porque, a inexistência de participação popular na estrutura organizacional das agências reguladoras deverá ser compensada pela busca à realização de princípios e valores fundamentais, bem como pela promoção à participação cidadã no processo decisório que venham a consagrar os preceitos de um Estado Democrático de Direito ${ }^{393}$.

Com essas considerações, mister esclarecer que há dois tipos de legitimidade democrática, quais sejam, a legitimação pelo título e a legitimação pelo exercício do poder. $\mathrm{O}$ primeiro diz respeito àqueles legitimados porque eleitos ou porque nomeados por quem foi eleito (caso das agências reguladoras), o que não necessariamente confere legitimidade plena, constituindo apenas uma faceta da legitimidade pelo título. Quanto ao segundo, este seria uma legitimidade conferida pelo exercício pleno do poder, isto é, mediante a efetiva perseguição dos interesses coletivos quando do exercício do poder.

Nessa linha de intelecção, Fábio Konder Comparato ${ }^{394}$ ensina que a legitimidade do Estado reside na sua capacidade de alcanças as finalidades públicas e não na expressão da soberania popular de eleger os seus representantes.

\footnotetext{
391 JUSTEN FILHO, Marçal. Agências Reguladoras e Democracia: Existe um Déficit Democrático na "Regulação Independente"? In: ARAGÃO, Alexandre Santos. (Org.). O Poder Normativo das Agências Reguladoras. Rio de Janeiro: Forense, 2006, p. 241

392 Ibidem, p. 243.

393 Canotilho aponta que o Estado Democrático de Direito ensejou a criação da chamada "Teoria do Estado Administrativo", sob a qual o Governo é o legítimo defensor da Lei Maior e dos direitos fundamentais. (CANOTILHO, Joaquim José Gomes. Direito Constitucional e Teoria da Constituição. 3 ed. Coimbra: Ed. Almedina, 1999, p. 1265).

394 COMPARATO, Fábio Konder. Juízo de Constitucionalidade das Políticas Públicas. In: Estudos em homenagem a Geraldo Ataliba. v. 2. São Paulo: Malheiros Editores, 1997, p. 350-351.
} 
Após as considerações delineadas quanto a relação existente entre democracia e o quadro contemporâneo das agências reguladoras aqui no Brasil, pode-se concluir, preliminarmente, que ante a existência de diversas vias de legitimidade democrática legitimidade pelo título e legitimidade pelo exercício do poder - ou seja, o conceito de democracia não se restringe puramente ao processo eletivo, haja vista que pressupõe também o respeito ao pluralismo, a garantia dos direitos e liberdades, o debate sobre as escolhas coletivas $^{395}$. Desta maneira, mostra-se insuficiente a simples inexistência de elegibilidade para a caracterização de um suposto déficit democrático.

Diante do que fora elucidado acima, é possível observar que não se coadunava com os objetivos por trás do modelo regulatório adotado no Brasil dar espaço à participação popular. Insta lembrar que a importação o desenho institucional adotado no Brasil contrasta-se essencialmente com o modelo estadunidense, pois o sistema regulatório brasileiro tinha por escopo maior a manutenção de um "status quo conservador".

Por tal razão, a percepção da suposta tensão entre as agências reguladoras e o regime democrático se deu de forma bastante tardia. Logo, imperativo um exame mais detalhado acerca da legitimidade pelo exercício do poder conferida por meio da participação da sociedade civil aos canais de comunicação com as referidas agências.

3.2 A Legitimidade Democrática das Agências Reguladoras: alcance das finalidades públicas e participação cidadã no processo decisório

Ante o exposto, nota-se que a legitimação democrática pode ser auferida sob diversas nuances, não se limitando exclusivamente ao processo eletivo. Nesse sentido, não se poderia afirmar a existência de "déficit democrático" nas agências reguladoras simplesmente em face da nomeação dos seus dirigentes, não observando que tais entes administrativos podem, ainda assim, congregar diversos valores democráticos, com a consecução das finalidades públicas, a neutralização de decisões majoritárias antidemocráticas, a concretização de valores e direitos fundamentais e, inclusive, dando espaço à participação popular no processo decisório de tais entes.

395 JUSTEN FILHO, Marçal. Agências Reguladoras e Democracia: Existe um Déficit Democrático na "Regulação Independente"? In: ARAGÃO, Alexandre Santos. (Org.). O Poder Normativo das Agências Reguladoras. Rio de Janeiro: Forense, 2006, p. 233. 
No entanto, resta insuficiente a mera existência formal das agências reguladoras para assegurar a ampliação de preceitos democráticos. Para tal intento, deve a estrutura organizacional das agências reguladoras estarem voltadas para o florescimento e a maturidade democrática, caso contrário, sua legitimação continuará deficitária.

Nesse ínterim, somente poderá afirmar a falta de legitimidade de tais entes administrativos quando o exercício de suas funções acarretar o aprofundamento das deficiências democráticas ou, simplesmente, fugir ao cumprimento das finalidades para a qual foram criadas.

Com base nessas premissas, Fernando Martins ${ }^{396}$ propõe um tripé que, sendo respeitado, conferirá legitimidade democrática ao exercício da função regulatória. Para tal intento, faz-se mister cumprir estritamente os seguintes pontos: a) atendimento das finalidades públicas fixadas para aquele setor econômico; b) presença de espaços públicos de discussão; e, por fim, c) sujeição aos princípios constitucionais.

Conforme se verá, o presente estudo se propõe a examinar a segunda faceta da referida tríade, estabelecendo a importância dos atuais canais públicos de participação cidadã existentes para a configuração de uma regulação setorial efetivamente democrática e eficiente.

Inclusive, mostrar-se-á que a participação cidadã no processo decisório das agências reguladoras é, de fato, ferramenta plenamente hábil ao atendimento das finalidades públicas, bem como para a concretização dos princípios e valores constitucionais, aprofundando o espírito democrático ${ }^{397}$.

Entretanto, a participação cidadã se dá de diversas formas e intensidade, conforme elucida Maren Taborda ${ }^{398}$. Há a classificação da participação popular uti singuli e uti cives. Na

\footnotetext{
${ }^{396}$ MARTINS, Fernando Barbalho. A legitimidade democrática das agências reguladoras. Revista de Direito processual Geral. n. 58, Rio de Janeiro, 2004, p. 83.

397 Aprofundando a questão, Diogo Pignataro, Fabiano Mendonça e Yanko Alencar ressaltam que: “[...] a regulação econômica se alia fortemente ao espírito da proteção e efetivação dos direitos fundamentais, dentre os quais se destaca, por fins de objeto de estudo, o direito ao desenvolvimento. É assim que a função reguladora, desenhada pelas instituições jurídicas criadas para exercê-la, relacionando uma gama de atribuições de variadas naturezas (informativas, planejadoras, fiscalizadoras, negociadoras, normativas, ordinatórias, gerenciais, arbitradoras e sancionadoras), pretende congregar as vantagens da flexibilidade negocial privada com o rigor da coercitividade estatal, de modo a atuar com um foco diferenciado na economia, de uma forma que, inclusive, propicia maiores condições ao Estado de dar uma relevância superior ao direito fundamental ao desenvolvimento.”. (OLIVEIRA, Diogo Pignataro; MENDONÇA, Fabiano André de Souza; XAVIER, Yanko Marcius de Alencar. A governança pública e o estado regulador brasileiro na efetivação do direito fundamental ao desenvolvimento. In: Regulação econômica e proteção dos direitos humanos: um enfoque sob a óptica do direito econômico. Org.: Fabiano André de Souza Mendonça; Vladimir da Rocha França; Yanko Marcius de Alencar Xavier. Fortaleza: Fundação Konrad Adenauer, 2008. p. 55).

398 TABORDA, Marem Guimarães. O princípio da publicidade e a participação na Administração Pública. 2006. 215 f. Tese (Doutorado) - Curso de Direito, Universidade Federal do Rio Grande do Sul, Porto Alegre, 2006, p. 191.
} 
primeira, o cidadão, como titular de direitos e interesses próprios, participa das decisões administrativa. Na segunda, o cidadão participa do processo decisório na condição de membro da coletividade, defendendo interesses gerais que afetam a um grupo de pessoas, determinadas ou não. A outra classificação divide a participação cidadã em direta, quando os cidadãos atuam de forma direta nas escolhas administrativas, e indireta, quando sua participação se faz por meio de representantes ou delegados. Por fim, há aqueles que defendem a participação-audição, em que a Administração Pública ouve e escuta os cidadãos diretamente afetados antes de tomar suas decisões, e a participação-negociação, na qual o ente público negocia com os cidadãos os interesses em jogo, visando o diálogo e a consensualidade, antes da escolha administrativa.

É que, ao contrário do que se pensou em um passado recente, as agências reguladoras podem ser uma valiosa e importante ferramenta de ampliação e consecução dos preceitos democráticos tutelados pelo ordenamento jurídico pátrio, o que constitui verdadeira evolução e aperfeiçoamento da organização estatal.

Aliás, as agências reguladoras podem configurar uma releitura da teoria clássica da tripartição dos poderes, à proporção em que atenua a concentração de poder nas mãos dos governantes eleitos, impedindo a chamada "ditadura da maioria", e, concomitantemente, protege e consagra direitos e garantias fundamentais.

A participação cidadão promove o controle político das decisões tomadas pelas agências, ampliando o compromisso destas instituições com os valores democráticos e com os princípios fundamentais.

A ausência de controles democráticos pode dar ensejo a decisões que, ainda que norteadas pela tecnicidade científica de tais entes, tenham um nítido caráter arbitrário. Ora, o simples argumento de que as decisões emanadas pelas agências de regime especial gozam de tecnicidade e eficiência e visam o interesse público mostra-se sobremaneira insuficiente. $\mathrm{Na}$ realidade, como bem observa Paulo Mattos ${ }^{399}$, “a própria noção de interesse público constituise como um lugar comum retórico onde tudo cabe" 400 .

\footnotetext{
399 MATTOS, Paulo Todescan Lessa. Regulação econômica e social e participação pública no Brasil. IX Congresso del CLAD sobre la Reforma del Estado y de la Administración Pública. Madrid, 2-5 nov, 2004. Anais eletrônicos... Madrid, 2004, p. 2.

${ }^{400}$ Sobre o tema, ver: SIQUEIRA, Mariana de. Interesse público no Direito Administrativo brasileiro: da construção da moldura à composição da pintura. Tese (Doutorado). Departamento de Direito, Universidade Federal de Pernambuco, 2014.
} 
Com sapiência, ensina Marçal Justen Filho 401 que "a concepção da agência independente legitima-se democraticamente não pela eleição dos seus membros, mas pela participação da sociedade na formação das decisões de competência da agência".

Nessa intelecção, a legitimidade pelo exercício do poder das agências de regime especial residiria justamente na busca constante dos interesses coletivos. E a perseguição desses objetivos pode ser proporcionada com a abertura do processo decisório das agências reguladoras à participação popular, mediante audiências públicas, consultas de opinião, debates públicos e outros instrumentos característicos de uma democracia mais participativa.

\section{CONSIDERAÇÕES FINAIS}

A existência das agências reguladoras brasileiras decorre de uma necessidade de mudança de perspectiva da atuação estatal na seara econômica, tornando-se menos intervencionista para adotar uma posição mais norteadora, fiscalizatória e reguladora de atividades econômicas que sejam de relevante interesse público, pautada em dois princípios basilares, a subsidiariedade e a proporcionalidade.

A fim de que os entes reguladores correspondessem as expectativas para as quais foram criadas, com imparcialidade, técnica e eficiência, estes foram dotados de uma autonomia qualificada e reforçada, que se caracteriza pela independência normativa, autonomia política, autonomia orgânica, independência financeira e orçamentária e pela independência técnicadecisional.

Com o conservadorismo e a morosidade natural do Legislativo, concedeu-se ao Poder Executivo a incumbência de regular setores chaves da economia de forma imparcial, célere e eficiente, fortalecendo este Poder e instrumentalizando-o.

Toda essa autonomia dada às agências fez com que uma série de críticas a seu respeito surgissem com base no receio de que se estivesse diante de um poder paralelo que escapa dos mecanismos de controle clássicos.

\footnotetext{
${ }^{401}$ JUSTEN FILHO, Marçal. Agências Reguladoras e Democracia: Existe um Déficit Democrático na "Regulação Independente"? In: ARAGÃO, Alexandre Santos. (Org.). O Poder Normativo das Agências Reguladoras. Rio de Janeiro: Forense, 2006, p. 233.
} 
Diante desse cenário, surgem discussões e críticas sobre a crise de legalidade atinente às agências reguladoras, a sua tensão com o princípio da separação dos poderes e a tensão com o regime democrático.

No entanto, há algum tempo o grande debate sobre as agências reguladoras deixou de se limitar à sua autonomia qualificada, como elemento indispensável à sua atuação imparcial, técnica e eficiente, desvinculada da subordinação hierárquica ao Executivo Central.

A discussão hodierna, conforme elucidado no presente trabalho, pauta-se na suposta ausência de legitimidade democrática e de mecanismos de controles (político, econômico e social) sobre tais entes administrativos. Ante essa constatação, foi necessário empreender esforços acadêmicos tendo por escopo estudar e diagnosticar o possível déficit democrático atribuído às agências reguladoras.

Como resultado, chegou-se ao consenso de que a participação popular no processo decisório dos entes reguladores seria uma importante ferramenta para conferir legitimidade democrática a tais entes, juntamente com uma atuação técnica, imparcial e eficiente que visasse a consecução do interesse público, por meio do fomento e proteção de direitos e valores constitucionais.

Isto porque, ao contrário da concepção clássica, a legitimidade democrática pode ser auferida não apenas pelo título, isto é, com o sufrágio universal, mas também pelo exercício do poder, pelo qual a atuação das agências se legitima pela perseguição incessante do interesse público.

\section{REFERÊNCIAS}

ARAGÃO, Alexandre dos Santos. O Atual Estágio de Regulação Estatal. In: ARAGÃO, Alexandre dos Santos. Agências Reguladoras e a Evolução do Direito Administrativo Econômico. 2 ed. Rio de Janeiro: Forense, 2005.

A Nova Jurisdição Constitucional Brasileira. Rio de Janeiro: Renovar, 2001.

BARROSO, Luís Roberto. Constituição, Ordem Econômica e Agências Reguladoras. Revista Eletrônica de Direito Administrativo Econômico. Instituto de Direito Público da Bahia, Salvador, fev/abr, 2005. 
BINENBOJM, Gustavo. Agências reguladoras, legalidade e direitos fundamentais - limites aos poderes normativo e sancionatório da ANVISA na regulação de produtos fumígenos. Revista de Direito Público da Economia, Belo Horizonte, v. 3, n. 10, abr. 2005, p. 486.

Uma Teoria do Direito Administrativo: Direitos Fundamentais, Democracia e Constitucionalização. Rio de Janeiro: Renovar, 2006,

BOBBIO, Norberto; MATTEUCCI, Nicola; PASQUINO, Gianfranco. Dicionário de Política. 5 ed. Brasília: Ed. Universidade de Brasília. 1999.

BRASIL. Constituição Federal de 1988. Disponível em: < http://www.planalto.gov.br/ccivil_03/constituicao/constituicaocompilado.htm>. Acesso em: 15 maio 2015.

CANOTILHO, Joaquim José Gomes. Direito Constitucional e Teoria da Constituição. 3 ed. Coimbra: Ed. Almedina, 1999

CASTRO, Carlos Roberto Siqueira. Função Normativa Regulatória e o Novo Princípio da Legalidade. In: ARAGÃO, Alexandre Santos. (Org.). O Poder Normativo das Agências Reguladoras. 2 ed. Rio de Janeiro: Editora Forense, 2005.

COMPARATO, Fábio Konder. Juízo de Constitucionalidade das Políticas Públicas. In: MELLO, Celso Antônio Bandeira (organizador). Estudos em homenagem a Geraldo Ataliba: direito administrativo e direito constitucional. São Paulo: Malheiros Editores, 1997.

FIDALGO, Carolina Barros. Déficit democrático e legitimação do modelo brasileiro de agências reguladoras independentes através da criação de mecanismos de participação dos administrados. II Prêmio SEAE, Rio de Janeiro, 2007.

FIGUEIREDO, Leonardo Vizeu. Lições de Direito Econômico. 2 ed. Rio de Janeiro: Forense. 2009,

GOMES, Thiago Beserra. O conceito de neoliberalismo. Instituto Ludwing von Mises Brasil. 2010 .

GRAU, Eros Roberto. A Ordem Econômica na Constituição de 1988. 5 ed. São Paulo: Malheiros Editores, 2000. 
JUSTEN FILHO, Marçal. Agências Reguladoras e Democracia: Existe um Déficit Democrático na "Regulação Independente"? In: ARAGÃO, Alexandre Santos. (Org.). O Poder Normativo das Agências Reguladoras. Rio de Janeiro: Forense, 2006.

MARTINS, Fernando Barbalho. A legitimidade democrática das agências reguladoras. Revista de Direito Processual Geral. n. 58, Rio de Janeiro, 2004.

MARTINS, Aluisio de Souza. Agências Reguladoras e os Riscos da Captura pelos Entes Regulados: Estudo Comparativo entre o Direito Regulatório Norte-Americano e o Brasileiro, 2010. Dissertação (Mestrado em Direito Internacional Econômico) - Faculdade de Direito, Universidade Católica de Brasília, Brasília, p. 80.

MATTOS, Paulo Todescan Lessa. Agências Reguladoras e Democracia: participação pública e desenvolvimento. In: SALOMÃO FILHO, Calixto (Org.). Regulação e Desenvolvimento. São Paulo: Malheiros, 2002.

MOREIRA, Egon Bockman. Agências Reguladoras Independentes, Déficit Democrático e a "Elaboração Processual de Normas". Revista de Direito Público da Economia - RDPE. Belo Horizonte, Ano 1, n., jan/mar, 2003

MOURA, Kate de Oliveira; XAVIER, Maria Augusta Marques de Almeida. A Participação Popular no Processo Decisório das Agências Reguladoras como Pressuposto Indispensável a uma Legítima e Eficiente Regulação Setorial Democrática. Revista Jurídica In Verbis (UFRN), v. 37, jan./jun. 2015, p. 52

OLIVEIRA, Diogo Pignataro; MENDONÇA, Fabiano André de Souza; XAVIER, Yanko Marcius de Alencar. A governança pública e o estado regulador brasileiro na efetivação do direito fundamental ao desenvolvimento. In: Regulação econômica e proteção dos direitos humanos: um enfoque sob a óptica do direito econômico. Org.: Fabiano André de Souza Mendonça; Vladimir da Rocha França; Yanko Marcius de Alencar Xavier. Fortaleza: Fundação Konrad Adenauer, 2008

SILVA, Eduardo Marques da. A independência das Agências Reguladoras no Brasil e o Projeto de Lei $\mathbf{n}^{\mathbf{0}}$ 3.337/2004. Rio de Janeiro. Prêmio SEAE, 2006

SIQUEIRA, Mariana de. Interesse público no Direito Administrativo brasileiro: da construção da moldura à composição da pintura. Tese (Doutorado). Departamento de Direito, Universidade Federal de Pernambuco, 2014. 
TABORDA, Marem Guimarães. O princípio da publicidade e a participação na Administração Pública. 2006. 215 f. Tese (Doutorado) - Curso de Direito, Universidade Federal do Rio Grande do Sul, Porto Alegre, 2006.

\title{
THE OVERCOMING OF THE EXISTING TENSION BETWEEN THE BRAZILIAN REGULATORY AGENCIES AND THE DEMOCRATIC REGIME
}

\begin{abstract}
The present study aims to study the Brazilian regulatory agencies from the perspective of the supposed democratic deficit attributed to these special regime autarchies. Initially, the premises will be highlighted regarding the relationship between democracy and regulatory agencies in the context of neoliberalism. Then, an analysis will be made on the tension between the Brazilian regulatory agencies and the democratic regime. Thus, comments will be made regarding the measurement of democracy within the regulatory model. The objective is to demonstrate the various possibilities of democratic legitimacy observed by the doctrine, namely: i) democratic legitimacy by the title, that is, by universal suffrage; Ii) legitimacy by the exercise of power, by which the agencies' performance is legitimized by the unceasing pursuit of the public interest. Following this, the issue of popular participation in the decision-making process of the regulatory agencies will be considered as an essential prerequisite for the achievement of a democratic sectorial regulation associated with the fulfillment of the public purposes destined to such entities.
\end{abstract}

Keywords: Brazilian Regulatory Agencies. Supposed Democratic Deficit. Legitimacy for the exercise of power. 